\title{
PEMANFAATAN APLIKASI GOOGLE FORM UNTUK MENINGKATKAN ANTUSIASME SISWA DALAM MENGERJAKAN ULANGAN PADA MATA PELAJARAN FIQIH
}

\author{
HARYANI \\ MTs Negeri 5 Klaten Jawa Tengah \\ Email : draharyanitulas@gmail.com
}

\begin{abstract}
ABSTRAK
Tujuan Penelitian best practice ini adalah untuk meningkatkan antusiasme siswa dalam mengikuti ulangan harian mata pelajaran Fiqih melalui google form pada pembelajaran jarak jauh. Di MTs Negeri 5 Klaten. Subyek dari penelitian ini adalah siswa kelas 7C MTs Negeri 5 Klaten pada semester genap tahun pelajaran 2020 / 2021. Penelitian ini menggunakan metode diskriptif kualitatif dengan tehnik analisis dikriptif kualitatif. Adapun teknik pengumpulan data melalui dokumen hasil belajar dan angket. Hasil penelitian ini menunjukkan bahwa siswa cenderung tertarik dengan penggunaan google form yang dirasakan lebih sederhana dan mudah dalam penggunaannya. Sehingga dapat disimpulkan bahwa google form dapat membangkitkan antusiasme siswa dalam mengikuti penilaian hasil belajar dan sekaligus dapat meningkatkan hasil belajarnya.
\end{abstract}

Kata Kunci : Aplikasi google form, Antusiasme, ulangan harian

\section{PENDAHULUAN}

Dalam sebuah proses pendidikan penilaian merupakan hal yang sangat penting karena penilaian merupakan tolok ukur keberhasilan sebuah proses pendidikan .Menurut peraturan Menteri Pendidikan dan Kebudayaan Nomor 20 tahun 2007 Tentang Standar Penilaian bahwa yang dimaksud dengan penialaian pendidikan adalah proses pengumpulan dan pengolahan informasi untuk menentukan pencapaian hasil belajar peserta didik. Hasil belajar merupakan bagian terpenting dalam pembelajaran. Nana sudjana (2009:3) mendifinisikan hasil belajar siswa pada hakikatnya adalah perubahan tingkah laku sebagai hasil belajar. Dimyati dan Mujiono (2006: 3-4) hasil belajar merupakan hasil dari suatu interaksi tindak belajar dan tindak mengajar. Dari sisi siswa hasil belajar merupakan akhir dari puncak proses belajar. sedangkan dari sisi guru tindak mengajar diakhiri dengan proses evaluasi hasil belajar. Berdasarkan pasal 1 Peraturan menteri Pendidikan dan kebudayaan Nomor 53 Tahun 2015 tentang penilaian Hasil Belajar oleh pendidik dan Satuan Pendidikan pada Pendidikan Dasar dan Pendidikan Menengah, Penilaian Hasil belajar oleh pendidik adalah proses pengumpulan informasi /data tentang capaian pembelajaran peserta didik dalam aspek sikap, aspek pengetahuan ,dan aspek ketrampilan yang dilakukan secara terencana dan sistematis melalui penugasan dan evaluasi hasil belajar. Penilaian ini dilakukan untuk memantau proses kemajuan belajar dan perbaikan hasil belajar melalui observasi,penilaian diri,penilaian teman sejawat,penugasan,ulangan,tes praktikdan porto folio yang disesuaikan dengan karakteristik kompetensi. Menurut Syaiful Bahri Djamarah \& Aswan Zain (2006 ) menyatakan,bahwa untuk mengukur dan mengevaluasi hasil belajar siswa tersebut dapat dilakukan melalui tes prestasi belajar. Adapun tes tersebut salah satunya berupa tes formatif atau ulangan harian. Ulangan harian adalah kegiatan yang dilakukan secara periodik untuk mengukur pencapaian kompetensi peserta didik setelah menyelesaikan satu kompetensi dasar (KD) atau lebih.Ulangan harian dilakuakan setiap selesai proses pembelajaran dalam kompetensi dasar tertentu. Ulangan harian ini terdiri dari seperangkat soal yang harus dijawab oleh peserta didik dan tugas-tugas terstrukturyang berkaitan dengan konsep yang sedang dibahas.(Permendiknas .2007).Tujuan dilaksanalkan ulangan harian ini untuk mengukur sejauh mana peserta didik menguasai kompetensi yang diharapkan, sekaligus sebagai feedback atau umpan balik bagi guru dalam melaksanakan pembelajaran.Ulangan Harian ini minimal dilaksanakan 3 kali dalam satu semester. 
Sejak diberlakukannya Surat Edaran Menteri Pendidikan dan kebudayaan Nomor 4 Tahun 2020 tentang Pelaksanaan Kebijakan Pendidikan dalam Masa Darurat (COVID - 19) bahwa Pendidikan dilaksanakan dari rumah melalui pembelajaran jarak jauh baik daring ataupun luring. Hal itu menyebabkan para guru mengalami kesulitan untuk melaksanakan evaluasi terhadap hasil belajar peserta didik. Sehingga belum bisa maksimal dalam memantau proses kemajuan belajar dan perbaikan hasil belajar. Seperti yang kami rasakan di Madrasah Tsanawiyah Negeri 5 Klaten khususnya pada mata pelajaran Fiqih di kelas 7C semester Genap Tahun Pelajaran 2020/2021. Peserta didik cenderung kurang antusias untuk mengerjakan ulangan harian yang diberikan baik lewat pesan whatsapp maupun lewat e-learning. Rendahnya semangat (antusiasme) peserta didik untuk mengerjakan ulangan harian tersebut disebabkan oleh kejenuhan mereka dalam mengikuti pembelajaran daring. Rendahnya antusiasme dalam pembelajaran tentu saja akan mempengaruhi hasil belajar peserta didik. Karena antusiasme merupakan kunci penting untuk mencapai kesuksesan. Pengertian antusisme Menurut Kamus Besar Bahasa Indonesia berasal dari kata "Antusias" yang berarti bergairah,bersemangat atau memiliki minat besar terhadap sesuatu. Antusiasme akan mendorong sesorang ke depan dan memenangkan perjuangannya ( Samuel.2015) dalam (Titik Suciati. 2018) . Jadi antusiasme merupakan gairah atau semangat yang ada pada diri seseorang sehingga seseorang tersebut memiliki minat yang besar untuk meraih kesuksesan. Begitu pula dalam pembelajaran jika peserta didik tidak memiliki antusiasme dalam belajar dapat dipastikan hasil belajarnya akan rendah. Dalam pembelajaran yang menjadi tolok ukur keberhasilan seseorang adalah apabila hasil belajarnya telah mencapai KKM (Kreteria Ketuntasan Minimal), jika peserta didik tidak memiliki antusisme didalam mengerjakan penilaian hasil belajar maka secara otomatis guru tidak dapat mengetahui perkembangan hasil belajarnya. Untuk itu seorang guru dituntut untuk berkreasi dan mencari strategi tertentu yang dapat menumbuhkan minat,semangat atau antusiasme peserta didik dalam mengerjakan penilaian hasil belajar.

Di era tehnologi industri 4.0 sudah seharusnya kita memanfaatkan teknologi dalam berkomunikasi secara online dan melakukan transformasi dalam proses pembelajaran khususnya dalam melaksanakan penilaian hasil belajar, dengan memanfaatkan teknologi yang sedang berkembang yaitu dengan menggunakan aplikasi berbasis web yang tersedia di google drive, salah satunya adalah google form. Google form adalah layanan dari google untuk kelola pendaftaran acara,jejak pendapat,membuat kuis dan melakukan kuis secara online. Pada google form terdapat tanggapan survey yang diolah menjadi grafik lingkaran (Hamdan Husein Batubara.2016). Melalui google form ini kita bisa mendapatkan jawaban langsung dari responden. Google form memiliki banyak keuntungan diantaranya google form ini dapat diakses secara gratis ,mudah dalam pengoprasian serta merupakan media yang efektif untuk penilaian. Kelebihan dari google form ini yang pertama kita dapat menampilkan tema yang unik dan menarik sesuai kebutuhan kita sehingga peserta didik akan lebih rileks saat mengisi googleform, kelebihan kedua dalam google form terdapat spread sheet yang akan mempermudah guru untuk mengetahui secara detail dan lengkap hasil yang telah dikerjakan oleh responden (peserta didik), Kelebihan lainnya dari google form adalah banyak menu pilihan kuis yang dapat diedit sesuai kebutuhan sehingga guru dapat memilih type soal apa saja yang akan dijadikan sebagai media evaluasi penilaian.

Berangkat dari latar belakang masalah yang ada di Madrasah Tsanwiyah negeri 5 Klaten khususnya pada mata pelajaran Fiqih di kelas 7C Semester Genap Tahun Pelajaran 2020/2021, maka penulis mengadakan penelitian ini dengan berasumsi bahwa pemanfaatan aplikasi google form dapat meningkatkan antusiasme siswa dalam mengerjakan ulangan mata pelajaran Fiqih. Dan dengan meningkatnya antusiasme belajar maka akan meningkat pula hasil belajar peserta didik. 


\section{METODE PENELITIAN}

Jenis penelitian ini adalah Penelitian Best practice yang merupakan salah satu pengalaman terbaik guru dalam mengatasi permasalahan-permasalahan yang terjadi pada saat pembelajaran, Best practice adalah cerita keberhasilan terbaik dalam menyelesaikan masalah ketika melaksanakan tugas sebagai Pendidik (Suryani.2017:5). Sedangkan menurut (Rohanah.2019) menyatakan bahwa best practice adalah suatu ide atau gagasan mengenai suatu teknik, metode, proses, aktivitas, intensif atau penghargaan (reward) yang lebih efektif dalam mencapai suatu keberhasilan.

Dalam penelitian ini penulis menggunakan metode penelitian diskriptif kualitatif yang menunjukkan adanya diskripsi terhadap fenomena tentang tanggapan peserta didik terhadap penggunaan google form sebagai media evaluasi dan disesuaikan dengan tujuan penelitian yaitu untuk meningkatkan antusiasme peserta didik dalam mengerjakan Ulangan Harian pada mata pelajaran fiqih dengan menggunakan google form. Tehnik pengumpulan data menggunakan angket dan dukumen tugas penilaian harian peserta didik yang dikumpulkan. selanjutnya data tersebut dianalisis dengan menggunakan tehnik analisis deskriptif kualitatif.

Teknik analisis diskriptif kualitataif diharapkan dapat menggambarkan antusiasme peserta didik dalam mengerjakan penilaian melalui google form Adapun Gambaran tentang antusiasme dapat diperoleh melalui data prosentase keikutsertaan peserta didik dalam mengikuti penilaian harian dengan cara menghitung banyaknya peserta didik yang mengikuti penilaian harian dengan membandingkan jumlah peserta didik yang tidak mengikuti penilaian harian dan dibandingkan dengan keseluruhan peserta didik.kemudian dikualifikasikan dengan menggunakan pedoman sebagai berikut :

\section{Tabel 1. Prosentase Keikutsertaan Peserta Didik Pada Penilaian Harian}

\begin{tabular}{lll}
\hline NO & Prosentase Keikutsertaan & Kualifikasi \\
\hline 1 & $81 \% \leq X \leq 100 \%$ & Sangat baik \\
2 & $61 \% \leq X \leq 80 \%$ & Baik \\
3 & $41 \% \leq X \leq 60 \%$ & Cukup \\
4. & $21 \% \leq X \leq 40 \%$ & Kurang \\
5. & $0 \% \leq X \leq 20 \%$ & Sangat kurang \\
\hline
\end{tabular}

Selanjutnya untuk mengetahui tingkat minat dan ketertarikan peserta didik terhadap google form sebagai media penilaian yaitu dengan menggunakan angket tentang tanggapan peserta didik terhadap proses penilaian dalam pembelajaran mata pelajaran fiqih yang menggunakan google form. Karakteristik minat dan motivasi peserta didik terhadap google form ini akan kita ukur dari sejauh mana ketertarikan peserta didik dalam mengenal google form. Ada 5 pertanyaan yang diajukan terhadap peserta didik diantaranya bagaimana tanggapan peserta didik terhadap pembelajaran fiqih yang menggunakan aplikasi google form sebagai media evaluasi, dan tanggapan tentang berbagai kelebihan dari google form.

Dalam penelitian ini angket yang digunakan adalah angket tertutup,dimana responden tinggal memilih jawaban yang sudah disediakan. Adapun penilaian terhadap angket (kuisener) tersebut dengan menggunakan skala sikap yaitu skala likert. Menurut Sugiono(2012:231) dalam( Muhammad Rizal Fauzi.2014) menyatakan bahwa skala likert digunakan untuk mengukur sikap, pendapat dan persepsi seseorang atau sekelompok orang tentang fenomena sosial. Skala likert yang digunakan adalah skala 1-5 dengan pilihan alternatif jawaban Sangat Setuju (5), Setuju (4), Ragu-Ragu (3), Tidak Setuju (2), Sangat Tidak Setuju (1). Kemudian dari hasil perolehan angka tersebut diporsentase dengan menghitungkan nilai yang diperoleh dibagi nilai maksimal dikalikan seratus porsen dengan menggunakan pedoman sebagai berikut 
Tabel 2. Prosentase Minat dan Ketertarikan Peserta Didik

\begin{tabular}{lll}
\hline NO & $\begin{array}{l}\text { Prosentase Minat dan } \\
\text { ketertarikan Peserta Didik }\end{array}$ & Kualifikasi \\
\hline 1 & $81 \% \leq X \leq 100 \%$ & Sangat baik \\
2 & $61 \% \leq X \leq 80 \%$ & Baik \\
3 & $41 \% \leq X \leq 60 \%$ & Cukup \\
4. & $21 \% \leq X \leq 40 \%$ & Kurang \\
5. & $0 \% \leq X \leq 20 \%$ & Sangat kurang \\
\hline
\end{tabular}

Selanjutnya untuk mengetahui rerata hasil belajar dapat kita hitung dengan cara membandingkan nilai yang diperoleh peserta didik dengan skor nilai maksimal dikalikan seratus. Kemudian dari perolehan nilai tersebut kita kualifikasikan secara verbal dengan berpedoman pada tabel 1 atau tabel 2. Subyek dari penelitian ini adalah siswa kelas 7C Mts Negeri 5 Klaten Tahun Pelajaran 2020 / 2021 pada Semester Genap yang berjumlah 30 orang yang terdiri dari 19 peserta didik laki-laki dan 11 peserta didik perempuan. Sedangkan obyek dari penelitian ini adalah antusiasme siswa dilihat dari keikutsertaan peserta didik dalam mengikuti tes Ulangan Harian dan hasil angket terkait tanggapan peserta didik terhadap penggunaan google form sebagai media evaluasi / penilaian hasil belajar.

Adapun kreteria ketuntasan dalam penelitian ini adalah meningkatnya antusiasme peserta didik dalam mengerjakan Ulangan Harian online yang dibuktikan dengan semakin meningkatnya partisispasi siswa dalam mengerjakan Penilaian Harian dan peningkatan hasil belajar siswa.

\section{HASIL DAN PEMBAHASAN}

\section{Hasil}

Dengan diberlakukannya pembelajaran jarak jauh yang sudah berjalan kurang lebih 1 tahun ini menyebabkan rendahnya semangat peserta didik dalam mengikuti pembelajaran, bahkan menjadikan mereka kurang peduli terhadap hasil belajarnya karena mereka berasumsi bahwa dalam kondisi seperti ini pasti akan selalu dimaklumi. Pola pemikiran seperti itu telah mempengaruhi tingkat antusiasmenya terhadap proses pembelajaran. Terbukti dari hasil penelitian ini yang menunjukkan tingkat partisipasi peserta didik dalam mengikuti ulangan Harian dan hasil belajarnya diperoleh data sebagai berikut :

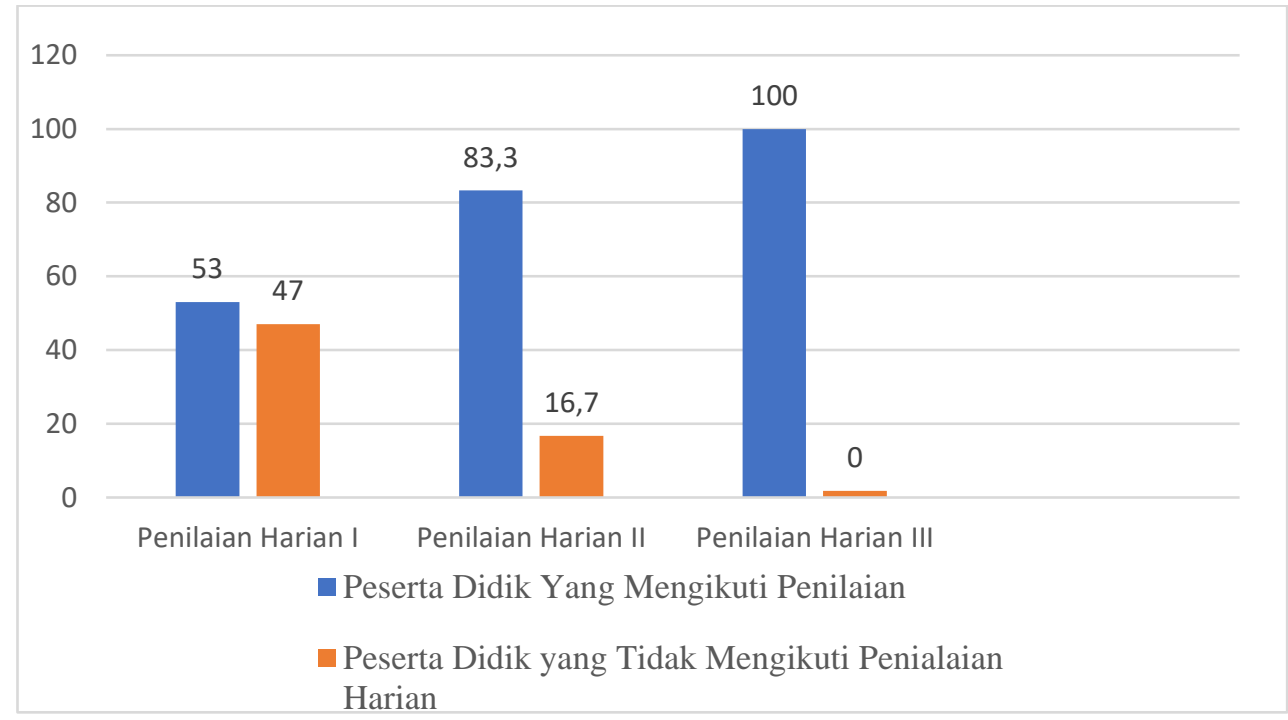

Gambar 3. Grafik Perbandingan Keikutsertaan Peserta Didik Pada Ulangan Harian 


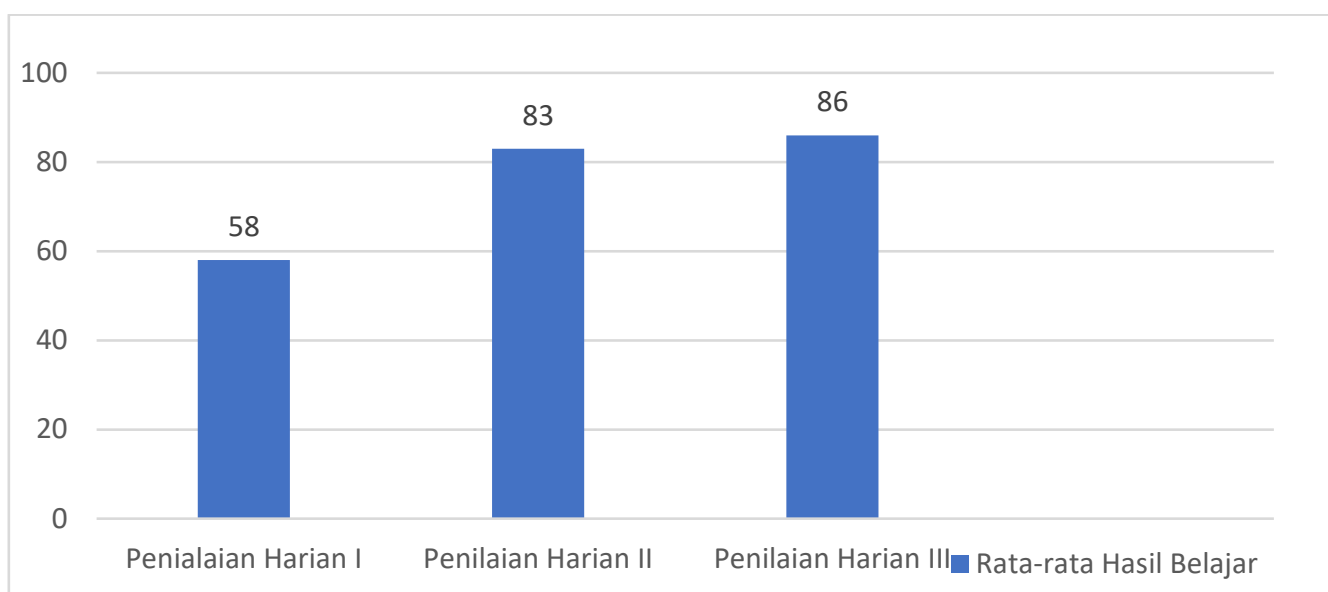

Gambar 4. Grafik Histogram Perbandingan Rata-rata Hasil Belajar

Dari hasil penelitian diperoleh data bahwa pada Ulangan Harian I yang dilaksanakan pada tanggal 26 Pebruari 2021 menunjukkan bahwa peserta didik kelas 7C dengan jumlah 30 siswa yang mengikuti ulangan harian I sebanyak 16 anak dan 14 anak tidak mengikuti dengan berbagai alasan lupa, banyak pekerjaan rumah, malas, bosan dan sebagainya. Sehingga diperoleh data sebesar $53 \%$ dari siswa kelas 7C MTs Negeri 5 Klaten mengikuti Penilaian Harian I dan 47\% siswa kelas 7C tidak mengikuti Ulangan Harian I, dengan rata-rata hasil belajar sebesar 58,00. Kemudian pada Ulangan Harian II yang dilaksanakan pada tanggal 6 Maret 2021 diperoleh data hasil penelitian sebagai berikut : Siswa yang mengikuti ulangan Harian II sebanyak 25 anak dengan prosentase sebesar 83,3\% sisanya 5 anak dengan porsentase sebesar 16,7\% tidak mengikuti Ulangan Harian II, dengan rata-rata hasil belajar sebesar 83,00. Selanjutnya pada Ulangan Harian III sebanyak 30 anak telah mengikuti Ulangan Harian III dengan prosentase sebesar $100 \%$ dengan rata-rata hasil belajar sebesar 86,00. Selanjutnya untuk mengetahui tingkat antusisme siswa dapat kita lihat dari hasil angket yang telah dikumpulkan melalui google form berikut :

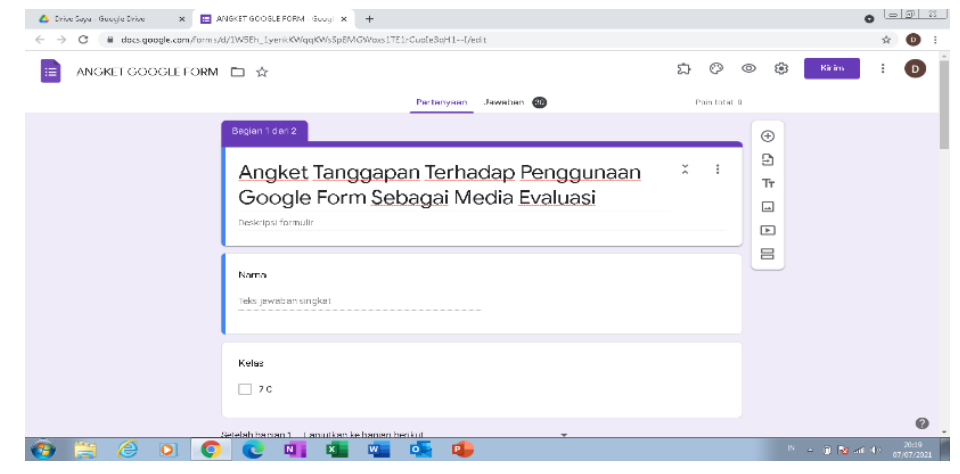

\section{Gambar 5. Angket Tanggapan Penggunaan Google Form}

Pertanyaan yang diajukan kepada 30 responden terhadap penggunaan google form diantaranya

1. Apakah responden setuju jika pembelajaran Fiqih menggunakan media online?

2. Apakah responden setuju jika dalam penilaian pembelajaran Fiqih menggunakan google form?

3. Responden tertarik mengerjakan ted online karena bisa dikerjakan dimana saja dengan menggunakan HP.

4. Responden tertarik mengerjakan tes di google form karena tampilan fiturnya menarik/ 
5. Responden tertarik mengerjakan tes di google form karena hasilnya dapat segera dilihat. Adapun hasil angket tanggapan 30 responden tersebut dapat kita lihat dari tabel berikut :

Tabel 3. Hasil Angket Terhadap Penggunaan Google Form

\begin{tabular}{|l|l|l|l|l|l|}
\hline No Soal & SS & S & R & TS & STS \\
\hline 1 & 8 & 9 & 8 & 4 & 1 \\
\hline 2 & 3 & 18 & 9 & 0 & 0 \\
\hline 3 & 18 & 10 & 2 & 0 & 0 \\
\hline 4 & 6 & 14 & 10 & 0 & 0 \\
\hline 5 & 18 & 12 & 0 & 0 & 0 \\
\hline Keterangan: \\
\hline SS \\
\hline S & : Setuju \\
\hline R & : Ragu-ragu \\
\hline TS & : Sangat Tidak Setuju \\
\hline STS &
\end{tabular}

\section{Pembahasan}

Berdasarkan tabel tersebut diatas dapat dikatakan bahwa keikutsertaan peserta didik dalam mengerjakan Ulangan Harian I diperoleh sebanyak $53 \%$ dari siswa kelas 7C MTs Negeri 5 klaten yang mengerjakan Ulangan Harian I. Sedangkan $47 \%$ siswa kelas 7C MTs Negeri 5 Klaten tidak mengerjakan Ulangan Harian I. Dengan demikian kualifikasi tingkat partisipasi peserta didik dalam mengikuti ulangan Harian I dalam kategori cukup rendah. Rendahnya partisipasi peserta didik ini diikuti pula rendahnya hasil belajar sebesar 58,00. Rendahnya partisipasi peserta didik dalam mengerjakan ulangan harian ini disebabkan faktor kejenuhan dalam Pembelajaran Jarak Jauh (PJJ). Selama ini penulis membuat soal dengan model CBT atau penugasan yang harus di Upload dalam e-learning ataupun lewat whatsapp. Dengan model semacam ini pada awalnya ada kemauan untuk mengerjakan tetapi ada sebagian anak yang tidak mengerjakan atau mengumpulkan tugas karena terkendala dalam upload tugas yang akhirnya mempengaruhi proses pembelajaran menjadi kurang interaktif, mereka jadi malas untuk mengerjakan dan mengumpulkan tugas walaupun sudah sering kali diingatkan bahkan diberikan perpanjangan waktu dalam pengumpulannya. Kondisi semacam ini tentu saja proses pembelajaran tidak dapat berjalan dengan baik, bahkan dapat dikatakan kurang berhasil.

Sebagai seorang guru yang berperan dalam proses pembelajaran tentu saja akan mmengupayakan agar proses pembelajaran menjadi lebih interaktif. Seorang guru harus selalu mencari strategi, alternatif dan terobosan-terobosan baru agar ada inovasi dalam pembelajaran, Inovasi dalam pembelajaran memang sangat diperlukan agar peserta didik merasakan suasana belajar baru yang menyenangkan sehingga dapat membangkitkan minat dan semangat baru dalam belajar. Menurut Arthur. (1963) dalam (Rahmayanti. 2016) merumuskan minat sebagai perasaan suka yang berhubungan dengan suatu reaksi terhadap suatu yang kusus atau situasi tertentu. Biasanya seseorang yang menyukai sesuatu maka akan memiliki perhatian yang sangat besar terhadap sesuatu yang disukainya. Begitu pula dalam belajar. Dengan perhatian yang besar dalam belajar maka akan meningkat pula hasil belajarnya. Adapun inovasi pembelajaran yang penulis lakukan adalah dengan memanfaatkan Aplikasi google form sebagai media evaluasi.

Dalam Ulangan Harian yang berikutnya Penulis merubah model pembuatan soal dan cara pengumpulannya dengan menggunakan aplikasi oogle form. Dengan aplikasi google form ini penulis membuat kuis atau soal dengan type multiple choise, walaupun banyak pilihan type. Penulis memilih type multiple choise karena type ini lebih efektif dan efisien tidak perlu 
mengoreksi hasilnya otomatis sudah muncul di sparedsheet. Kemudian soal dikirimkan melalui google untuk mendapatkan link yang selanjutnya link tersebut kita berikan kepada anak-anak. Dengan melalui link tersebut para siswa dapat membuka dan mengerjakan kuis atau soal yang diberikan oleh guru tersebut dengan menggunakan android ataupun laptop. Selanjutnya pada Ulangan Harian II yang dilaksanakan pada tanggal 6 Maret 2021 setelah menerapkan google form sebagai media penilaian hasil belajar diperoleh data hasil penelitian sebagai berikut : Anak didik yang mengikuti Ulangan Harian II sebanyak 25 anak dengan prosentase sebesar $83,3 \%$ sisanya 5 anak dengan porsentase sebesar 16,7\% tidak mengikuti Ulangan Harian II. Berdasarkan data tersebut dapat dikatakan bahwa ada peningkatan sebesar 30\% peserta didik yang mengikuti Ulangan Harian II. Maka berdasarkan data tersebut kualifikasi tingkat partisipasi peserta didik pada Ulangan Harian II ini dalam kategori sangat baik. Dengan demikian dapat kita katakan bahwa telah terjadi peningkatan yang cukup signifikan pada Ulangan Harian II ini walaupun masih ada 5 anak yang tidak mengikuti Ulangan Harian II. Peningkatan ini dikuti pula dengan peningkatan hasil belajar sebesar 83,00.

Peningkatan ini terjadi karena ada pola baru, suasana belajar yang lebih interaktif sehingga tingkat antusiasme peserta didik meningkat, peningkatan antusiasme ini juga terjadi karena adanya ketertarikan peserta didik dalam menggunakan aplikasi google form, yang mereka rasakan lebih simpel, mudah dan sederhana, bahkan peserta didik dapat melihat langsung hasil pekerjaannya. Ketertarikan dan minat peserta didik dalam menggunakan google form sebagai media evaluasi ini dapat kita lihat dari hasil angket yang penulis sampaikan melalui form tanggapan peserta didik terhadap Pembelajaran Fiqih pada proses Pembelajaran Jarak Jauh (PJJ) maupun pada pelaksanaan evaluasi hasil belajar melalui google form.

Dari hasil angket diperoleh data sebesar $73 \%$ responden (peserta didik) menyetujui jika pembelajaran Fiqih dilaksanakan secara oneline dan sebesar $76 \%$ responden (peserta didik) menyetujui tentang penggunaan google form untuk melaksanakan Penilaian Hasil Belajar Mata pelajaran Fiqih. Kemudian sebesar $91 \%$ responden (peserta didik) tertarik untuk mengerjakan tes online karena bisa dikerjakan dengan HP, selanjutnya 77\% responden (Peserta didik) lebih tertarik dengan google form karena tampilan fiturnya lebih menarik daripada tes di e-learning atau whatsapp dan sebesar $92 \%$ responden (Peserta didik) menyukai google form karena dapat melihat hasil pekerjaan secara langsung. Rerata hasil angket tanggapan terhadap penggunaan google form sebagai media evalusi pembelajaran tersebut sebesar $82 \%$. Dengan demikian dapat dikatakan bahwa $82 \%$ peserta didik lebih tertarik terhadap google form sebagai media evaluasi hasil belajar. Maka berdasarkan hasil angket tersebut prosentase kualifikasi tingkat minat dan antusiasme peserta didik pada kategori sangat baik atau sangat tinggi.

Kemudian pada penilaian yang ketiga penulis mencoba untuk mencari strategi yang lebih intensif disamping penggunaan google form sebagai media evaluasi juga memanfaatkan whatsapp group sebagai sarana untuk melaporkan hasil pekerjaan peserta didik ketika mereka selesai mengerjakan ulangan harian. Dalam hal ini anak didik wajib melaporkan hasil pekerjaan mereka. Dengan cara pelaporan hasil pekerjaan lewat whatsapp group tersebut membuat peserta didik lebih serius dalam mengerjakan ulangan, karena ada perasaan malu jika hasil pekerjaan mereka nilainya kurang bagus lebih-lebih jika mereka tidak mengerjakan tentu mereka akan lebih malu. Dengan cara tersebut ternyata sangat efektif untuk meningkatkan antusiasme dan hasil belajar peserta didik. Terbukti pada hasil penelitian pada Penilaian Harian III diperoleh data sebesar $100 \%$ peserta didik mengikuti Ulangan Harian dengan rata-rata hasil belajar sebesar 86,00 .

Berdasarkan hasil penelitian tersebut diatas dapat kita ketahui bahwa sebesar $100 \%$ peserta didik telah mengikuti Ulangan harian III, Dengan demikian Antusiasme siswa dalam mengikuti Ulangan Harian telah meningkat $100 \%$ dan tingkat kualifikasinya pada kategori sangat baik. Dengan meningkatnya antusiasme maka meningkat pula hasil belajarnya dengan rata-rata sebesar 86,00. Dengan demikian kualifikasi hasil belajar peserta didik pada Ulangan Harian III dalam kategori sangat baik. 


\section{KESIMPULAN}

Berdasarkan hasil penelitian dan pembahasan tentang tingkat antusiasme peserta didik dalam mengikuti Penilaian Hasil Belajar pada mata pelajaran Fiqih dapat dilihat dari tingkat partisipasi atau keikutsertaan peserta didik dalam mengerjakan Ulangan Harian yang di adakan selama proses pembelajaran. Pada Pembelajaran Jarak Jauh ini sangat diperlukan adanya strategi yang efektif dalam proses penilaian hasil belajar peserta didik, dimana pada Pembelajaran Jarak Jauh ini terdapat banyak kendala dalam pelaksanaan Evaluasi Hasil Belajar diantaranya kejenuhan merupakan faktor yang mempengaruhi rendahnya antusiasme peserta didik dalam mengikuti pembelajaran sehingga mereka menjadi malas dan tidak tertarik untuk mengerjakan Ulangan Harian.

Ketertarikan terhadap sesuatu merupakan faktor yang dapat menumbuhkan semangat atau antusiasme terhadap sesuatu yang menjadi tujuan. Menurut Tjiptadinata Effendi dalam Kompasiana dalam Titik suciati (2018) mengatakan bahwa antusias adalah kekuatan terpenting dalam hidup sehingga menjadi kunci meraih sukses. Maka dalam Pembelajaran Jarak Jauh ini perlu ditumbuhkan antusiasme atau semangat dalam belajar. Untuk menumbuhkan antusiasme tersebut perlu ada strategi dan pola baru dalam pembelajaran maupun dalam pelaksanaan evaluasi hasil belajar sehingga hasil belajar peserta didik dapat terukur. Salah satu strategi yang diterapkan dalam mengukur hasil belajar peserta didik adalah penggunaan aplikassi google form sebagai media evaluasi. Aplikasi google form sebagai media evaluasi juga memiliki banyak kelebihan diantaranya sangat sederhana dan sangat mudah dalam penggunaan, hasilnya dapat segera diketahui secara langsung hal ini juga memudahkan guru dalam membuat soal maupun dalam koreksi hasil evaluasi. Karena hasil evaluasi sudah secara otomatis terekam dalam spreadsheet dan setiap saat diperlukan tinggal membukanya.

Dengan adanya strategi baru, pola pembelajaran dan model penilaian yang baru seperti aplikasi google form yang ditearpakan dalam Penilaian Hasil Belajar menunjukkan adanya perubahan yang signifikan yang mempengaruhi tingkat antusiasme peserta didik. Terbukti dari hasil penelitian menunjukkan adanya peningkatan partisipasi peserta didik dalam mengikuti Ulangan harian yaitu sebesar $53 \%$ pada ulangan Harian I dengan rata-rata ketuntasan belajar sebesar 58,00, kemudian pada Ulangan harian II sebesar 83,3\% dengan rata-rata ketuntasan belajar sebesar 83,00 dan pada Ulangan Harian III sebesar 100\%. Dengan rata-rata ketuntasan belajar 86,00. Peningkatan ini disebabkan adanya ketertarikan peserta didik dalam mengerjakan Ulangan Harian melalui aplikasi google form yang dirasakan lebih mudah dan sangat sederhana dalam penggunaannya bahkan bisa dikerjakan dimana saja dengan menggunakan Handphone. Dengan meningkatnya antusiasme peserta didik dalam mengikuti Ulangan Harian juga berpengaruh besar terhadap hasil belajar peserta didik yaitu dengan rata-rata sebesar 86,00. Dengan demikian dapat disimpulkan bahwa penerapan google form sebagai media evaluasi pada mata pelajaran fiqih sangat efektif untuk meningkatkan antusiasme peserta didik dalam mengerjakan penilaian hasil belajar dan dengan meningkatnya antusisme maka meningkat pula hasil belajarnya.

Hasil penelitian ini sesuai dengan penelitian yang dilakukan sebelumnya oleh Hamdan Husein Batubara tentang penggunaan google form sebagai alat penilaian kinerja dosen di prodi PGMI uniska Muhammad Arsyad Al banjari dan Muhammad Rizal Fauzi bahwa google form dapat menjadi salah satu software yang direkomendasikan untuk membuat alat penilaian online,tampilan mukanya dan cara menggunakannya cukup sederhana sehingga mudah dimengerti. google form sebagai alat evaluasi pembelajaran memberikan dampak dan manfaat baik dari aspek efektif,efisien,daya tarik dan desain tampilan. Bagi guru sangat terbantu dari segi biaya, waktu dan tenaga dan bagi siswa menjadi lebih tertarik,antusias dan aktif dengan demikian sudah tidak diragukan lagi bahwa penggunaan google form sebagai alat evaluasi belajar mata pelajaran Fiqih dapat membangkitkan semangat (antusiasme ) peserta didik dalam belajar dan sekaligus dapat meningkatkan hasil belajar. 


\section{DAFTAR PUSTAKA}

Badan Pembinaan dan Pengembangan Bahasa Departemen pendidikan Nasional. 2005. Kamus Besar Bahasa Indonesia . Jakarta : Balai Pustaka

Batubara. Hamdan Husein. 2016. Penggunaan google Form Sebagai Alat penilaian Kinerja Dosen Di Prodi PGMI Uniska Muhammad Arsyad Al Banjari. Al-Bidayah: Jurnal Pendidikan Dasar Islam 8(1)

Dimyati dan Mudjiono. (2006). Belajar dan Pembelajaran.Jakarta : PT Rineka Cipta

Djamarah. Syaiful Bahri dan Aswan Zain. (2006). Strategi Belajar Mengajar. Jakarta : PT Rineka Cipta

Fauzi, muhammad Rizal. (2014). Penggunaan Google Form Sebagai Alat Evaluasi Pembelajaran Pada Mata Pelajaran Bahasa Indonesia .Universitas Pendidikan Indonesia repository.upi.edu perpustakaan.upi.edu

Peraturan Menteri Pendidikan dan kebudayaan Nomor 20 Tahun 2007 Tentang Standar Penilaian

Peraturan Menteri pendidikan dan Kebudayaan Nomor 53 Tahun 2015 Tentang Penilaian Hasil Belajar

Rahmayanti.V. (2016).Pengaruh minat belajar siswa dan Persepsiatas Upaya Guru dalam memotivasi Belajar Siswa Terhadap Prestasi Belajar bahasa Indonesia siswa SMP Di Depok.SAP (Susunan Artikel Pendidikan).journal.lppmunindra.ac.id.II(2)

Rohanah.E. (2019). Publikasi Ilmiah Pengembangan Profesi Guru. Banjar Rangdu : CV Media Educations

Suciati.Titik. (2018). Meningkatkan Antusiasme Siswa Terhadap Kegiatan Belajar Dan Pembelajaran Di Kelas Melalui Program LiterASI Membaca “Tunggu Aku”. Insani.

Pemikiran Alternatif.ejournal.iainpurwokerto.ac.id

Sudjana.Nana. (2011).Penilaian Hasil Proses Belajar Mengajar. PT.Remaja Rosda Karya

Surat Edaran Menteri Pendidikan Dan Kebudayaan Nomor 4 Tahun 2020 Tentang Pelaksanaan Kebijakan Pendidikan Dalam Masa Darurat Penyebaran Coronavirus Disease (COVID -19)

Suryani. E. (2017). Best Practice : Pembelajaran Inovasi Melalui Model Project Basic Learning. Yogyakarta : Deepublish CV Budi Utama 